\title{
5 The economic potential of Polish voivodeships and Ukrainian oblasts
}

\author{
Nataliia Chugaievska, Oleksii Kelebaj and \\ Tomasz Tokarski
}

\subsection{Introduction}

The purpose of this chapter is to analyze the spatial diversity of the economic potential of Polish voivodeships and Ukrainian oblasts. Absolute economic potential is equated with the amount of GDP. Relative economic potential is understood as GDP per capita.

The timeframe and sources of statistical data are the same as those used in Chapter 4.

\subsection{Economic potential of Polish voivodeships}

Map 5.1 illustrates the spatial diversity of GDP in voivodeships in 20042016. The following conclusions can be drawn from this map and data on this macroeconomic variable: ${ }^{1}$

- The highest levels of GDP in 2004-2016 were recorded in the Mazowieckie (PLN 331.4 billion, 21.6\% of Polish GDP), Śląskie (PLN 196.8 billion, 12.8\%) and Wielkopolskie (PLN 146.9 billion, 9.6\%) voivodeships. A high level of this variable was also recorded in the Dolnośląskie (127.8 billion PLN, 8.3\%), Małopolskie (118.7 billion PLN, 7.7\%) and Łódzkie (PLN 94.3 billion, 6.1\%) voivodeships.

- The group of voivodeships with a low value of this variable included the Zachodniopomorskie (PLN 59.0 billion, 3.8\%) Warmińsko-Mazurskie (PLN 41.9 billion, 2.7\%) and Świętokrzyskie (PLN 38.9 billion, 2, 5\%) voivodeships. However, the group of voivodeships with the lowest value of this variable was composed of the Podlaskie (PLN 34.8 billion, 2.3\%), Lubuskie (PLN 34.8 billion, 2.3\%) and Opolskie (PLN 33.6 billion, $2.2 \%$ ) voivodeships.

- When comparing GDP data for 2004 and 2016 in individual voivodeships, it turns out that the value of this variable increased in each of these voivodeships. The largest (exceeding $60 \%$ ) increases in this macroeconomic variable were recorded in the following voivodeships: 


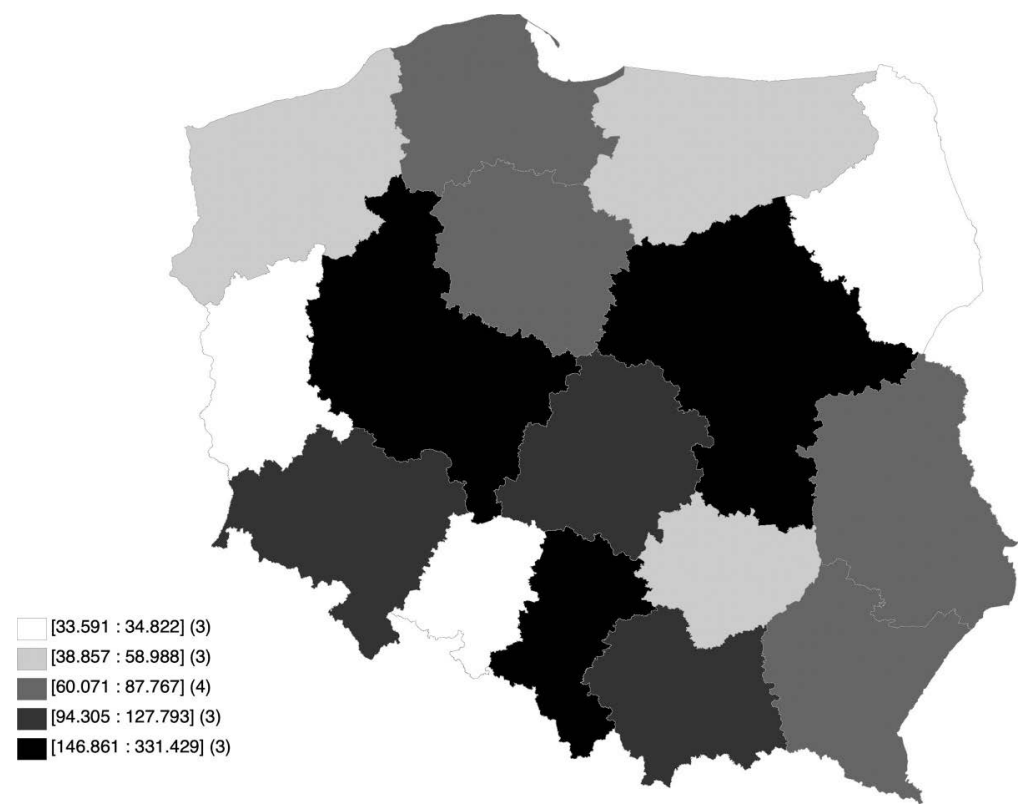

Map 5.1 GDP in voivodeship groups in 2004-2016 (PLN billion, according to 2015 prices)

Source: Our own estimates based on: https://bdl.stat.gov.pl/BDL/start (access: 2019-12-30).

Mazowieckie by $70.1 \%$ (4.2\% on average annually), Dolnośląskie by $70.5 \%$ (4.5\%), Małopolskie by $64.6 \%$ (4.2\%), Wielkopolskie by $63.7 \%$ $(4.2 \%)$ and Pomorskie by $61.5 \%$ (4.1\%). The lowest increases in this variable were recorded in the Śląskie 39.9\% (2.8\%), Opolskie 36.6\% (2.6\%) and Świętokrzyskie $35.7 \%$ (2.6\%) voivodeships.

- In the voivodeships of central Poland, in the years $2004-2016,36.9 \%$ of the Polish GDP was generated, in the voivodeships of western Poland it was $26.2 \%$, in the Mazowieckie Voivodeship $21.5 \%$, while in the five voivodeships of eastern Poland only $15.4 \%$.

- Figure 5.1 illustrates the trajectories of GDP in the Mazowieckie Voivodeship and other groups of voivodeships. This graph shows the following:

- In the voivodeships of central Poland, GDP increased from PLN 450.6 billion in 2004 to PLN 678.2 billion in 2016. In the voivodeships of western Poland the value of this macroeconomic variable increased from PLN 306.3 billion to PLN 487.1 billion, in the Mazowieckie Voivodeship from PLN 241.6 billion to PLN 413.1 billion, while in the voivodeships of eastern Poland from 188.7 billion PLN billion to PLN 276.8 billion. 


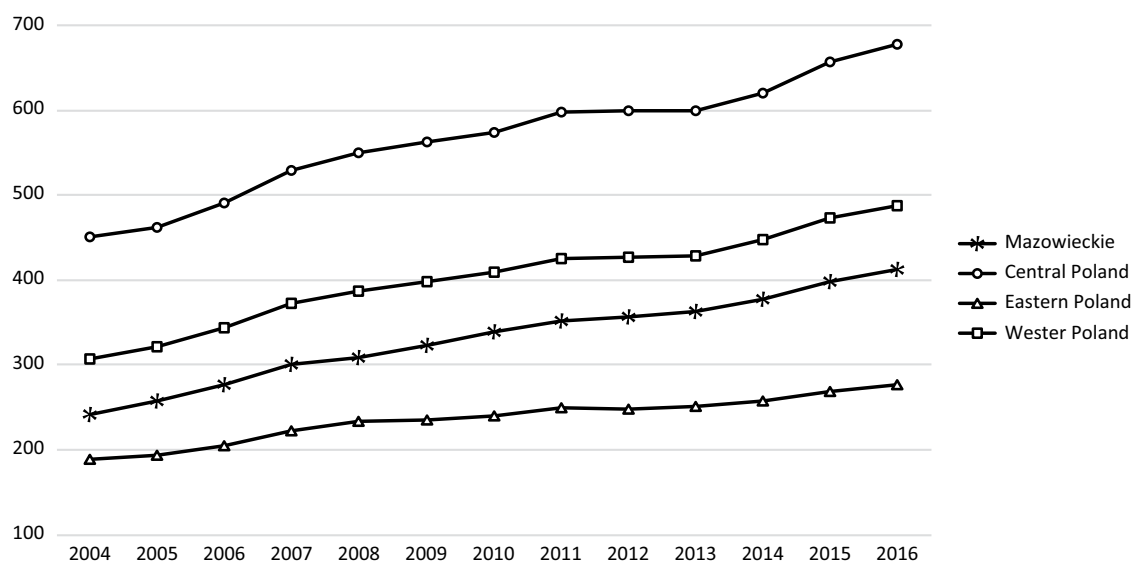

Figure 5.1 GDP in voivodeship groups in 2004-2016 (PLN billion, according to 2015 prices).

Source: Our own estimates based on: https://bdl.stat.gov.pl/BDL/start (access: 2019-12-30).

- On average, in 2004-2016, the Polish GDP grew at a rate of 3.8\%. The value of this variable was rising the fastest before the global crisis, that is, before 2009 (the average annual GDP growth rate was 5.1\% at the time). In 2010-2013, the growth rate of this variable in Poland dropped to $1.9 \%$, before rising to $4.2 \%$.

- In 2004-2009, GDP grew the fastest in the Mazowieckie Voivodeship $(6.0 \%)$, then in the voivodeships of western Poland (5.4\%) and central Poland (4.6\%), and the slowest in the voivodeships of eastern Poland (4.5\%).

- During the economic slowdown (2009-2013) caused by the global financial crisis, the Mazowieckie Voivodeship continued to develop the fastest $(2.9 \%)$ followed by the voivodeships of western Poland $(1.9 \%)$ and central Poland and eastern Poland (1.6\% each).

- $\quad$ Starting from 2013, the average annual GDP growth rate in the Mazowieckie Voivodeship increased to $4.4 \%$, in western Poland to $4.3 \%$, in central Poland to $4.2 \%$ and in eastern Poland to $3.3 \%$.

- As a result of these changes, the shares of the Mazowieckie Voivodeship and the voivodeships of western Poland in the creation of the Polish GDP increased, while in the other two groups of voivodeships it decreased. And so the share of the Mazowieckie Voivodeship grew from $20.4 \%$ to $22.3 \%$ and in the voivodeships of western Poland from $25.8 \%$ to $26.3 \%$. The share of the voivodeships of central Poland in GDP fell from $38.0 \%$ to $36.6 \%$, while in the voivodeships of eastern Poland it declined from $15.9 \%$ to $14.9 \%$. 


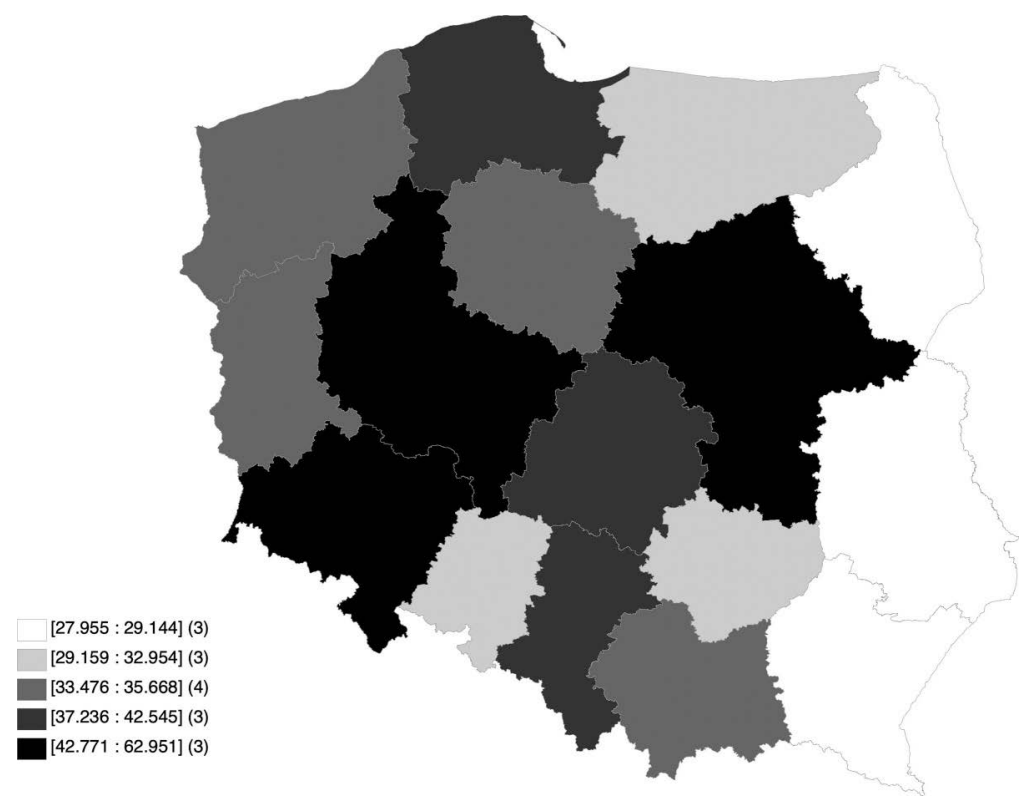

Map 5.2 GDP per capita in voivodeships in 2004-2016 (PLN, in thousands, according to 2015 prices)

Source: Our own estimates based on: https://bdl.stat.gov.pl/BDL/start (access: 2019-12-30).

Map 5.2 illustrates the spatial differentiation of GDP per capita in Poland's voivodeships in the research period (see also Figure 5.2 - in the groups of Poland's voivodeships). The following conclusions can be drawn from this figure (see also, for example, Tokarski 2005a; Trojak, Tokarski 2013; Mroczek et al. 2014; Filipowicz, Tokarski 2015; Trojak 2015 or Filipowicz 2017, 2019):

- The Mazowieckie Voivodeship had by far the highest GDP per capita (PLN 63.0 thousand), which resulted mainly from the economic potential of Warsaw together with the Warsaw agglomeration and the city of Płock. The Dolnośląskie (44.1 thousand) and Wielkopolskie (PLN 42.8 thousand) voivodeships in western Poland were also characterized by very high levels of this variable.

- The group of voivodeships with a high GDP per capita included the three voivodeships of central Poland: Śląskie (PLN 42.5 thousand), Pomorskie (PLN 38.8 thousand) and Łódzkie.

- However, the group of voivodeships with a low, and the lowest GDP per capita, included the Opolskie Voivodeship (PLN 33.0 thousand) from western Poland and five voivodeships from eastern Poland: Świętokrzyskie (30.5 thousand PLN), Warmińsko-Mazurskie (29.2 thousand) PLN), 
Podlaskie (PLN 29.1 thousand), Podkarpackie (28.4 thousand PLN) and Lubelskie (28.0 thousand PLN).

- As in the case of GDP, the GDP per capita in 2016 in each voivodeship was higher than in 2004. The fastest GDP per capita increase was in Dolnośląskie (by $69.9 \%$, i.e., $4.5 \%$ on average per year), Mazowieckie $(64.0 \%, 4.2 \%)$, Małopolskie $(58.7 \%, 3.9 \%)$, and Wielkopolskie $(58.3 \%$, $3.9 \%$ ) and Łódzkie $(57.5 \%, 3.9 \%)$. The lowest increases in this variable were recorded in the following voivodeships: Opolskie $(44.6 \%, 3.1 \%)$, Zachodniopomorskie (44.3\%, 3.1\%), Śląskie (44.2\%, 3.1\%), KujawskoPomorskie $(43.9 \%, 3.1 \%)$ and Świętokrzyskie $(39.6 \%, 2.8 \%)$.

Figure 5.2 presents the trajectories of GDP per capita in voivodeship groups. The following conclusions can be drawn from this figure:

- The shape of these trajectories was similar to the trajectory of GDP, as the variability of GDP was much greater than the variability of the population.

- The GDP per capita of the Mazowieckie Voivodeship in 2004 was higher than the value of this variable in each of the other groups of voivodeships at the end of the research period.

- The GDP per capita of the voivodeships of western Poland in 2004 accounted for $65.2 \%$ of the value of this variable in the Mazowieckie Voivodeship, whereas in central Poland it was $64.8 \%$ and in eastern Poland only $49.0 \%$. In 2016, these indicators were (respectively) 62.6\% (western Poland), 59.4\% (central Poland) and 44.2\% (eastern Poland).

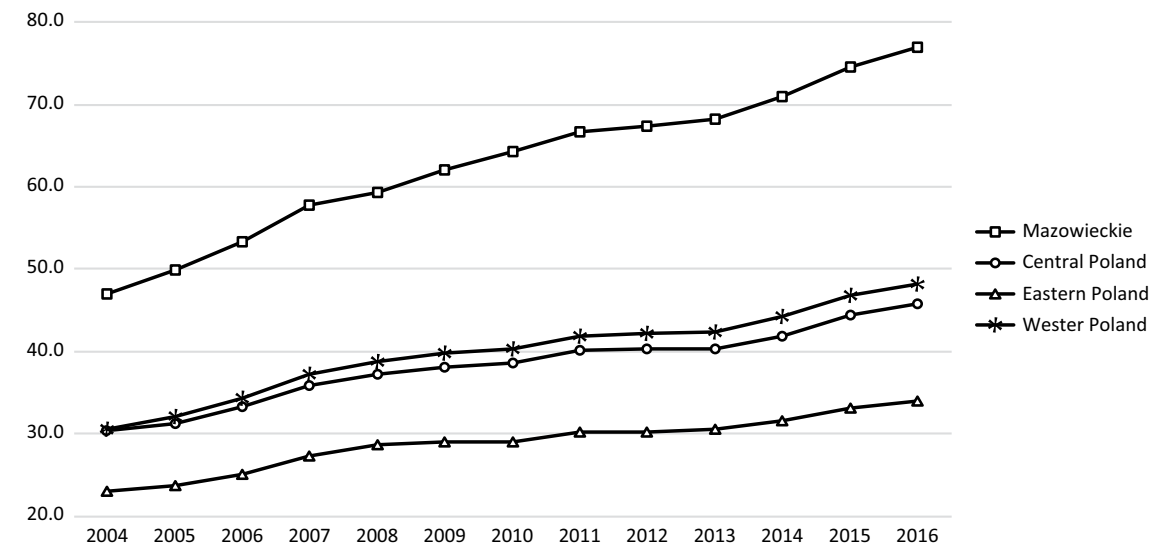

Figure 5.2 GDP per capita in voivodeship groups in 2004-2016 (PLN, in thousands, according to 2015 prices).

Source: Our own estimates based on: https://bdl.stat.gov.pl/BDL/start (access: 2019-12-30). 


\subsection{Economic potential of Ukrainian oblasts}

Map 5.3 illustrates the spatial differentiation of GDP in the oblasts of Ukraine in 2004-2017. The following conclusions can be drawn from this map (see also Chugaievska, Tokarski 2018; Tokarski et al. 2019 or Anilovska et al. 2019): ${ }^{2}$

- Almost every five UAH (20\%) of the Ukrainian GDP is produced in the capital of Kyiv (which is both the administrative and political center as well as the scientific, educational, service, communication and financial center of Ukraine). ${ }^{3}$ On average, in 2004-2017 Kyiv's GDP was about 0.5 trillion UAH (19.5\% of Ukrainian GDP).

- The group of oblasts with a GDP of 100-300 billion UAH included Donetsk (271.3 billion UAH, $10.5 \%$ of Ukraine's GDP), Kharkiv (154.8 billion UAH, 6.0\%) and Zaporizhzhya (108.0 billion UAH, 4.2\%) in eastern Ukraine; Dnipropetrovsk (261.6 billion UAH, 10.1\%) and Poltava (105.4 billion UAH, 4.1\%) in central Ukraine; Odesa (123.6 billion UAH, 4.8\%) in southern Ukraine; Kyiv (111.5 billion UAH, 4.2\%) in the north of Ukraine; and Lviv (106.9 billion UAH, 4.1\%) in the west of Ukraine.

- In 11 oblasts and one city with a special status (Sevastopol), the average annual GDP in 2004-2017 (or 2004-2013 in the case of Sevastopol) did not exceed UAH 50 billion. The statistics in the following oblasts were as follows: Khmelnytskyi (47.0 billion UAH, 1.8\% of Ukraine's GDP), Rivne (40.4 billion UAH, 1.6\%), Zakarpattia (36.7 billion UAH, 1.4\%), Volyn (36.4 billion UAH, 1.4\%), Ternopil (31.3 billion UAH, 1.2\%) and

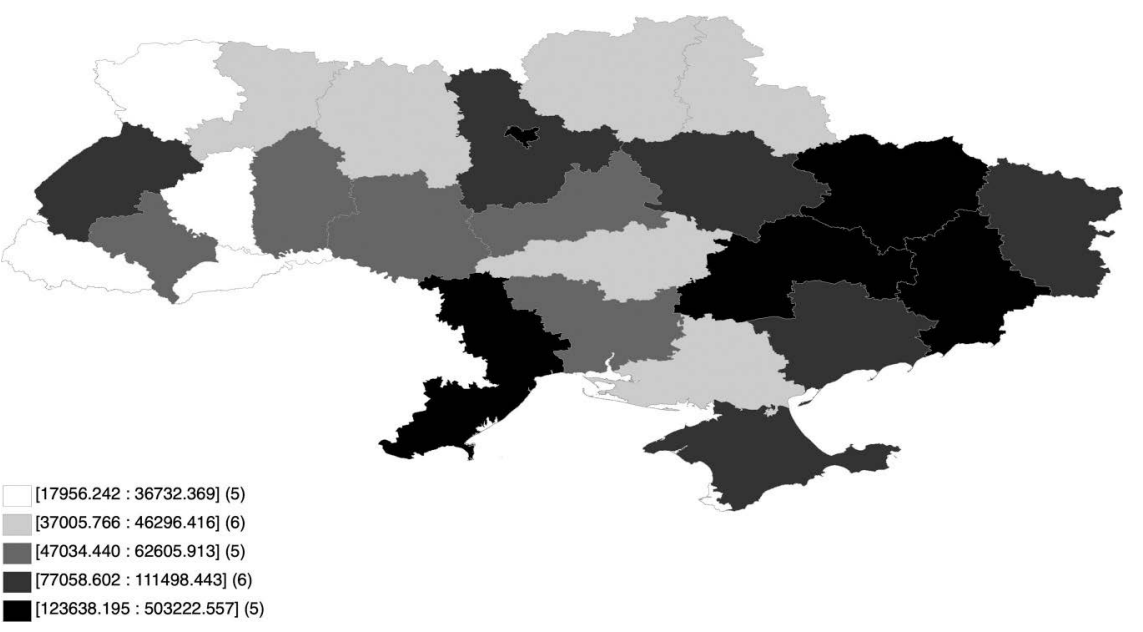

Map 5.3 GDP in oblasts in 2004-2017 (UAH million, according to 2016 prices) Source: Our own estimates based on: http://www.ukrstat.gov.ua/ (access: 2019-12-30). 
Chernivtsi (23.6 billion UAH, 0.9\%) in western Ukraine; Sumy (46.3 billion UAH, 1.8\%), Zhytomyr (44.4 billion UAH, 1.7\%) and Chernihiv (43.0 billion UAH, 1.7\%) in northern Ukraine; Kirovohrad (41.2 billion UAH, 1.6\%) in central Ukraine; and Kherson (37.0 billion UAH, 1.4\%) and a city with a special status, that is Sevastopol ${ }^{4}$ (18.0 billion UAH, $0.7 \%$ ), in the south of Ukraine.

- Regarding the oblast groups, the oblasts of northern Ukraine generated on average $29.3 \%$ of the Ukrainian GDP in 2004-2013 (Kyiv itself, as already mentioned, had $19.5 \%$ ), eastern Ukraine $24.4 \%$, central Ukraine $20.6 \%$, western Ukraine $14.7 \%$ and southern Ukraine $11.1 \%$.

- Hence, we may come to a more general conclusion that the greatest economic potential of Ukraine was concentrated in Left-bank Ukraine (Kyiv, the Kyiv region, the city of Dnipro, the Donbas, Kharkiv, Zaporizhzhya), in two coastal oblasts (Odesa and Mykolayiv) and the Lviv Oblast in western Ukraine. Kyiv, as already mentioned, is an administrative, communication center of Ukraine. The city of Dnipro is the center of financial services of the country, and an important center of political, cultural and educational life in central Ukraine. Kharkiv, Zaporizhzhya and Donbas are the main centers of the Ukrainian heavy and mining industries. The high level of economic development of the Odesa Oblast is mainly associated with the port of Odesa. Mykolayiv and the Mykolayiv region are a very important communication junction (road, rail, sea, river and air) in the south of Ukraine, and Lviv is by far the most prominent, demographically and economically, city in the west of the country (see also Chugaievska et al. 2017, 2019 or Chugaievska, Tokarski 2018).

Figure 5.3 illustrates the trajectories of GDP in the oblasts on average in 2004-2017. This graph shows the following:

- When analyzing the development of the GDP trajectory in oblast groups, the timeframe analyzed here should be divided into five subperiods. In the years 2004-2008, the Ukrainian economy was developing very dynamically. However, in the years 2008-2009 the global financial crisis and the Russian-Ukrainian gas conflict led to a significant decline of the GDP in Ukraine. In 2010-2013, the Ukrainian economy returned to the path of rapid economic growth, while in 2014-2015 (i.e., the first years after the Euro-Maidan) a deep recession occurred in the Ukrainian economy as a result of the political and military conflict with Russia (Crimea) or pro-Russian separatists (Donbas). However, in 2016-2017 the Ukrainian GDP slowly began to increase again.

- In the years 2004-2008, the oblast groups of eastern and northern Ukraine were characterized by the highest absolute economic potential (in the order of 600-800 billion UAH). The average, according to Ukrainian conditions, were those regions located in the center of 


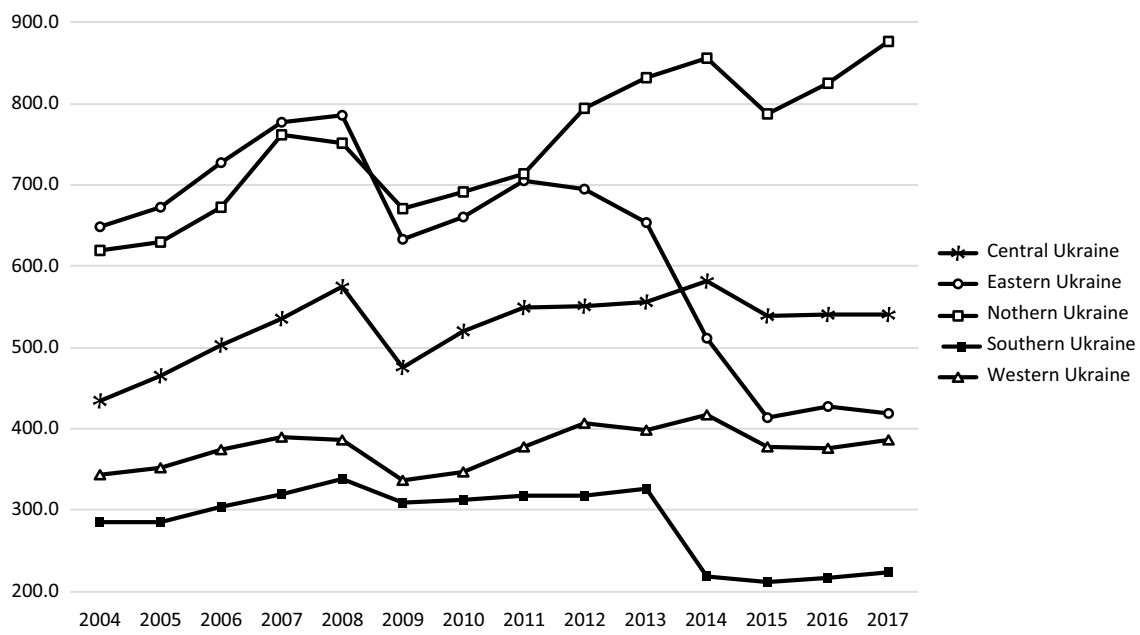

Figure 5.3 GDP in oblast groups in 2004-2017 (UAH billion, according to 2016 prices).

Source: Our own estimates based on: http://www.ukrstat.gov.ua/ (access: 2019-12-30).

Ukraine (430-580 billion UAH), while the lowest were the regions of western Ukraine (340-390 billion UAH) and the southern part of the country (280-340 billion UAH).

- In 2004-2008, the GDP grew the fastest in central Ukraine (at a 7.2\% yearly average), followed by northern $(5.0 \%)$, eastern $(4.9 \%)$, and southern Ukraine (4.4\%), with the slowest GDP increase noted in western Ukraine (3.0\%). As a result, the share of individual oblast groups in the production of the Ukrainian GDP changed as follows: the share of central Ukraine increased from $18.6 \%$ to $20.2 \%$, northern Ukraine remained unchanged (26.5\%), eastern Ukraine fell from $27.8 \%$ to $27.7 \%$, southern Ukraine decreased from $12.3 \%$ to $11.9 \%$, and western Ukraine fell from $14.7 \%$ to $13.6 \%$.

- The global financial crisis combined with the Ukrainian-Russian gas conflict affected quite significantly the most highly industrialized regions of eastern Ukraine (where GDP fell by 19.3\%) and central Ukraine (a decline of 17.1\%). In western Ukraine, the GDP fell by 12.7\%, in the north by $10.8 \%$ and in the oblasts of southern Ukraine only by $8.8 \%$. This resulted in an increase in the share of western Ukrainian oblasts in the Ukrainian GDP by 1.1 percentage points, southern Ukrainian oblasts by 0.8 of a percentage points, western oblasts by 0.3 of a percentage point and a decrease in the share of central Ukrainian oblasts by 0.6 of a percentage point and eastern Ukraine by 1.6 points.

- An economic recovery after the Russian-Ukrainian gas conflict resulted in the development of the regions of northern Ukraine $5.5 \%$ yearly 
average) the fastest, then western $(4.2 \%)$, central (4.0\%), and southern Ukraine (1.4\%), and the slowest progress in oblasts located in the east of the country (only $0.8 \%$ ). In 2013, the oblasts in the north of Ukraine already produced $30.1 \%$ of Ukraine's GDP (an increase of 3.5 percentage points compared to 2004), the east $23.6 \%$ (a decrease of 4.2 percentage points), the center $20.1 \%$ (an increase of 1.4 percentage points), the west $14.4 \%$ (a decrease of 0.3 of a percentage point) and the south $11.8 \%$ (a decrease of 0.4 of a percentage point).

- The political-military conflict with Russia after the Euro-Maidan also strongly influenced the country's economy. It affected (most obviously) the eastern Ukrainian oblasts (where the struggle with pro-Russian separatists in the Donbas is still ongoing, with a greater or lesser intensity) and southern Ukraine (the annexation of the Autonomous Republic of Crimea with Sevastopol).

- In eastern Ukraine oblasts, in 2014-2015 the GDP fell by $20.5 \%$ at a per annum average. However, the decrease in this macroeconomic value was not equal in all regions of this part of Ukraine. In the Luhansk region, the GDP in 2015 was as much as $72.0 \%$ lower than in 2013, in the Donetsk region by $55.0 \%$, in the Kharkiv region by $5.6 \%$, and in the Zaporizhzhya region by $5.7 \%$.

- In the oblasts located in the south of Ukraine, the GDP in 2013-2015 fell by $35.4 \%$. However, this was mainly the result of the annexation of the Crimean Peninsula by Russia. If one compares the total GDP of the three remaining regions of this part of Ukraine (i.e., Kherson, Mykolayiv and Odesa), it turns out that in 2013-2015, the GDP fell by 5.2\%.

- In the remaining groups of oblasts in the first two years after the EuroMaidan, drops in the GDP were not as drastic as in the east and south of Ukraine. The average annual rates of decline of this macroeconomic variable in central Ukraine were $1.5 \%$, in northern Ukraine $2.7 \%$ and in the western part of the country $2.5 \%$.

- As a result of these changes, the share of northern Ukrainian oblasts in the generation of Ukraine's GDP increased to $33.8 \%$, the central part of the country to $23.1 \%$, western Ukraine to $16.2 \%$, while the share of eastern Ukrainian oblasts fell to $17.7 \%$ and in the south to $9.1 \%$.

- In 2016-2017, the Ukrainian economy began to expand again. The GDP in northern Ukraine grew at an average annual rate of $5.5 \%$, while in the south by $2.9 \%$. The value of this variable increased much more slowly in western $(1.1 \%)$, eastern $(0.6 \%)$ and central Ukraine $(0.2 \%)$.

- The effect of these changes was that the GDP in 2017 in three out of the five oblast groups considered here was higher than in 2004. In the regions of northern Ukraine, the value of this variable increased by $41.6 \%$ ( $2.7 \%$ annual average), central Ukraine by $24.4 \%(1.7 \%)$ and western Ukraine by $12.8 \%$ ( $0.9 \%)$. In eastern Ukraine, the GDP in 2017 was lower than at the beginning of the research period by $35.6 \%$ (an average annual decrease of $3.3 \%$ ), while in southern Ukraine by $21.7 \%$ 
(a decreases of $1.9 \%$ ). However, if we consider only the Mykolayiv, Odesa and Kherson oblasts, it turns out that the GDP increased here between 2001 and 2017 by $9.8 \%$ (a $0.7 \%$ yearly average).

- When comparing the absolute value of GDP in 2004 and 2017 in the 25 regions of Ukraine (excluding the Autonomous Republic of Crimea and Sevastopol), it turns out that in 21 of these regions the GDP increased and in four regions it fell (in Chernivtsi and Zakarpattia in western Ukraine and in Donetsk and Luhansk in eastern Ukraine). The highest (exceeding 30\%) increases in this macroeconomic variable were recorded in the Kyiv Oblast (68.6\%, $4.1 \%$ per annum), in the City of Kyiv $(44.9 \%, 2.9 \%)$ in the north of Ukraine and in the Vinnytsya $(37,3 \%$, $2.5 \%)$ and Cherkasy $(30.2 \%, 2.0 \%)$ oblasts, in the center of the country (Map 5.4). In the Luhansk Oblast, the GDP fell by as much as $72.7 \%$ ( $9.5 \%$ on average per year), in the Donetsk Oblast by $58.7 \%(6.6 \%)$, in the Zakarpattia Oblast by $10.0 \%(0.8 \%)$ and in the Chernivtsi Oblast by $3.7 \%(0.3 \%)$.

- In Sevastopol, the GDP in 2013 was 34.4\% higher than in 2001 (and therefore the GDP grew annually at a rate of $3.3 \%$ ), while in the Autonomous Republic of Crimea, it increased at this time by $26.0 \%$ (an average annual growth of $2.6 \%$ ).

- Map 5.1 illustrates the spatial diversity of GDP per capita in oblasts during 2004-2017 (see also Figure 5.4). The following conclusions can be drawn from this figure:

- The capital of Kyiv had by far the highest value of this macroeconomic variable (179.9 thousand UAH). However, if we aggregate the GDP per

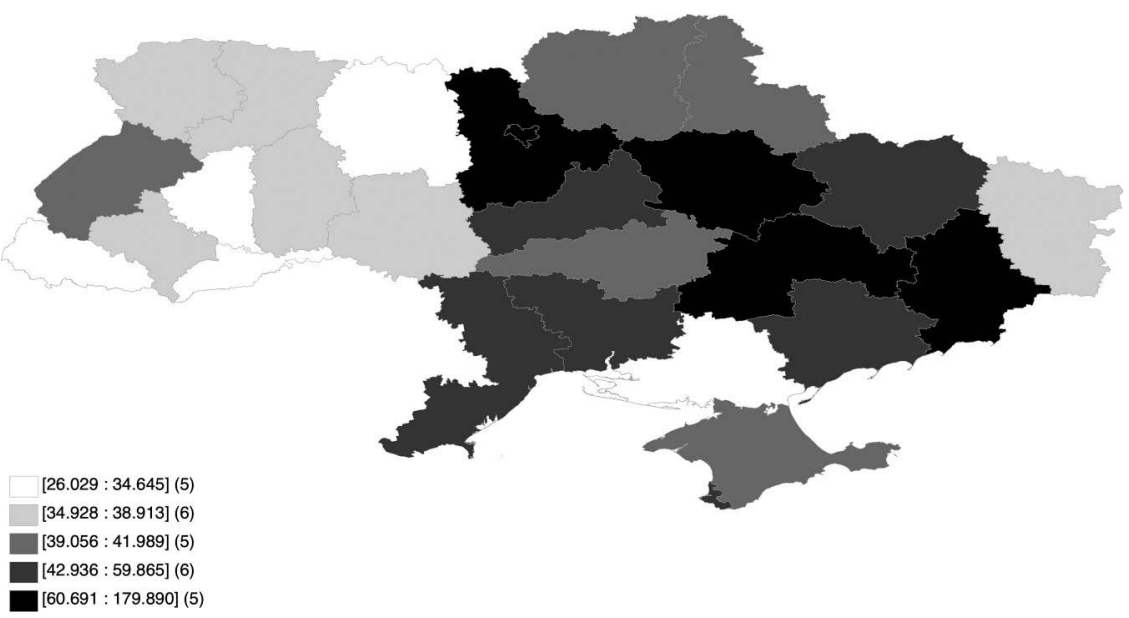

Map 5.4 GDP per capita in oblasts in 2004-2017 (UAH, in thousands, according to 2016 prices)

In the case of the ARC and Sevastopol in 2004-2013.

Source: Our own estimates based on: http://www.ukrstat.gov.ua/ (access: 2019-12-30). 
capita of an inhabitant of Kyiv together with the Kyiv Oblast (which may be compared with the capital-Mazowieckie Voivodeship in Poland, or with the Kharkiv, Odesa or Dnipropetrovsk oblasts in Ukraine), the average GDP per capita falls here to a level of 129.3 thousand UAH.

- The Dnepropetrovsk (78.3 thousand UAH), Poltava (70.9 thousand UAH) and Kyiv (64.3 thousand UAH) had a rather high GDP per capita (for Ukrainian conditions), a result which was also characteristic of the Donetsk region in the Donbas (60,700 UAH).

- Those oblasts located in the Dnieper valley (except for the Kherson Oblast), eastern Ukrainian oblasts and the Odesa and Mykolayiv coastal oblasts were characterized by the highest level of the macroeconomic variable analyzed here(GDP per capita). This is due to the fact that (first of all) in this part of Ukraine there are nine of the ten largest Ukrainian cities (except Lviv) and (second) the region of the Dnieper valley is very strongly influenced by the economic ripple effects from the rest of Ukraine (Chugaievska et al. 2017).

- Of the five oblasts with the lowest GDP per capita, three were located in the west, and one in the north and south of Ukraine. These oblasts were Zakarpattia (29.4 thousand UAH), Ternopil (28.9 thousand UAH) and Chernivtsi (26.0 thousand UAH) in western Ukraine; Zhytomyr (34.6 thousand UAH) in northern Ukraine; and Kherson (33.9 thousand UAH) in southern Ukraine.

- In general, the oblasts of Left-bank Ukraine together with the Black Sea oblasts of Odesa and Mykolayiv were characterized by a higher level of GDP per capita than the Right-bank oblasts (with the exception of the Lviv Oblast, which maintained an average GDP per capita of 42,000 UAH).

- Comparing the data on GDP per capita in 2017 with the value of this variable from 2001, in 25 out of 27 Ukrainian oblasts (excluding the Autonomous Republic of Crimea and Sevastopol), it turns out that - as in the case of GDP - in 21 of these oblasts the value of this variable increased, while in four (the Chernivtsi and Zakarpattia oblasts in western Ukraine, and the Donetsk and Luhansk oblasts in eastern Ukraine) this value fell.

- The highest (exceeding 30\%) per capita GDP growth was recorded in the following oblasts: Kyiv (an increase of 73.3\%, average annual growth of $4.3 \%)^{5}$ in northern Ukraine, Vinnytsya $(50.5 \%, 3.2 \%)$ and Cherkasy $(45.4 \%, 2.9 \%)$ in central Ukraine, Khmelnytskyi $(35.8 \%, 2.4 \%)$ in the west of Ukraine, Dnipropetrovsk $(34.3 \%, 2.3 \%)$ in central Ukraine, Zhytomyr (34, 0\%, 2.3\%) and in City Kyiv (33.1\%, 2.2\%) in the north of Ukraine, while in the Kirovohrad (32.7\%, 2.2\%) and Poltava (32.1\%, $2.2 \%$ ) oblasts in central Ukraine.

- In the Chernivtsi Oblast, the GDP per capita in 2017 was $2.8 \%$ lower than in 2001 (an average annual decrease of $0.2 \%$ ), in the Zakarpattia region it fell by $10.4 \%$ (0.8\% annual average), in the Donetsk GDP it fell by $53.9 \%$ (5.8\% on average per year), while in the Luhansk Oblast, the GDP declined by as much as $69.2 \%(8.6 \%)$. 
- In Sevastopol, the 2013 GDP per capita was 32.3\% higher than in 2001 (and therefore the GDP grew annually at a rate of $3.2 \%$ ), while in the Autonomous Republic of Crimea as a whole, it increased by $21.8 \%$ (an average annual growth of $2.6 \%$ ).

- Figure 5.4 illustrates the trajectories of GDP per capita in groups of Ukrainian oblasts. This graph shows the following:

- Trajectories of GDP per capita in oblast groups are similar in shape to the trajectory of GDP. This is due to the fact that in the research period in Ukraine (as in Poland), the variability of GDP in the oblast groups was much greater than the volatility of the population.

- By far the highest GDP per capita (mainly due to Kyiv and, to a lesser extent, the Kyiv Oblast) was recorded in the group of oblasts of northern Ukraine. Moreover, no other group of oblasts in 2004-2017 attained the level of GDP per capita of the oblasts of northern Ukraine from 2004.

- In the group of industrial oblasts of eastern Ukraine (characterized by the GDP per capita in 2004, the highest after that of northern Ukraine), as a result of the gas conflict with Russia in 2009 and the struggle with pro-Russian separatists in Donbas, the value of this variable dropped from 54.5 thousand UAH in 2004 to 38.7 thousand UAH in 2017 (therefore by $29.0 \%$ ).

- The GDP per capita in the central Ukrainian oblasts was (on average throughout the entire research period) about 32.9\% higher than in southern Ukraine and $70.4 \%$ higher than in western Ukraine. However, in relation to the GDP per capita of northern Ukraine, the value of this variable in central Ukraine amounted to $64.9 \%$.

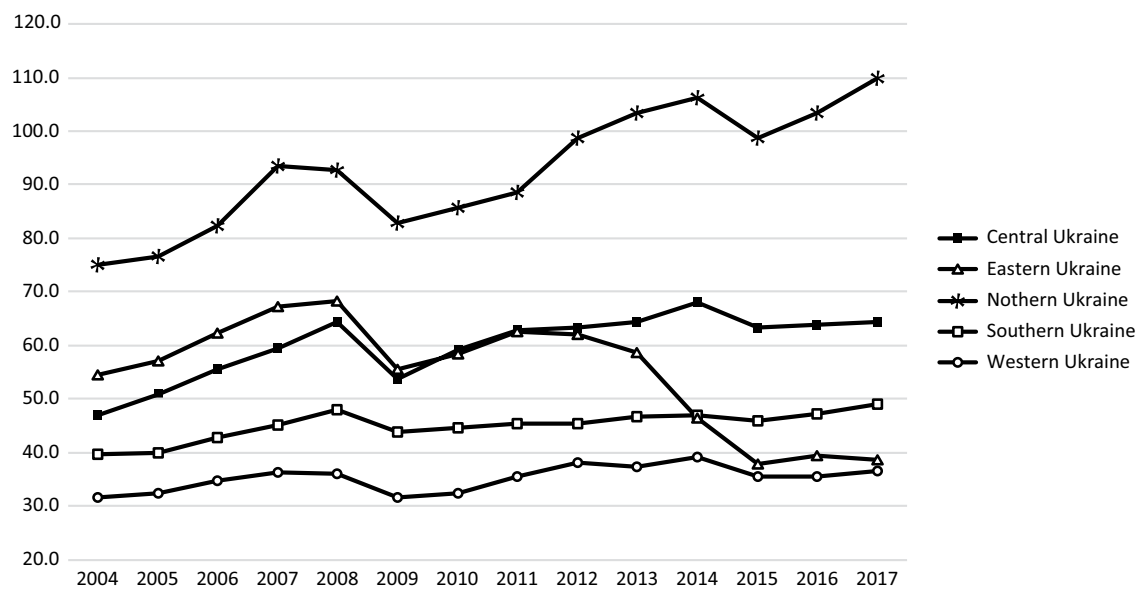

Figure 5.4 GDP per capita in oblast groups in 2004-2017 (UAH, in thousands, according to 2016 prices).

Source: Our own estimates based on: http://www.ukrstat.gov.ua/ (access: 2019-12-30). 


\subsection{Summary}

i As in the case of demographic potential, the largest economic potential (measured in GDP) was recorded in the Mazowieckie, Śląskie and Wielkopolskie voivodeships. The lowest economic potential was recorded in the Podlaskie, Lubuskie and Opolskie voivodeships.

ii By far the highest GDP level in 2004-2017 was recorded in the capital City of Kyiv, where literally every 5th UAH (20\%) of Ukraine's GDP was generated. A high level of this macroeconomic variable was also recorded in the Donetsk, Kharkiv and Zaporizhzhya regions located in eastern Ukraine. Nevertheless, the lowest absolute economic potential was found in the Zakarpattia, Volyn, Ternopil and Chernivtsi oblasts in western Ukraine as well as in Kherson and in the special status city of Sevastopol in southern Ukraine.

iii The largest part of the Polish GDP in 2004-2016 was generated by the voivodeships of central Poland $(36.9 \%)$, followed by western Poland (26.2\%), the Mazowieckie Voivodeship (21.5\%), and the smallest part by the voivodeships of eastern Poland (15.4\%).

iv In Ukraine (mainly due to Kyiv and, to some extent, the Kyiv Oblast), the largest part of GDP was generated by the northern regions of the country (29.3\% of Ukrainian GDP). Next in line were (the most industrialized) oblasts of eastern Ukraine (24.4\%), the oblasts of central Ukraine (20.6\%), and those of western Ukraine (14.7\%). However, the oblasts of southern Ukraine had the lowest economic potential (11.1\%).

$\mathrm{v}$ The GDP in voivodeship groups rose the most rapidly prior to the global financial crisis, and grew the slowest during the crisis itself.

vi On the other hand, the Ukrainian economy (and groups of oblasts) developed the fastest right up until the global financial crisis and the Russian-Ukrainian gas conflict. After a one-year recession in 2009, the economy returned to a path of economic growth, which was interrupted by a deep recession resulting from the political and military conflict with Russia and the pro-Russian separatists. This recession hit the two oblasts of Donbas particularly hard, which significantly weakened the economic potential of eastern Ukraine.

vii By far the highest GDP per capita in 2004-2016 was recorded in the Mazowieckie Voivodeship. A high GDP was also recorded in the Dolnośląskie and Wielkopolskie voivodeships. The lowest GDP per capita was recorded in the Opolskie Voivodeship and the five voivodeships of eastern Poland.

viii As in the case of absolute GDP, the capital City of Kyiv had the highest GDP per capita, by far. Next in line were the Dnipropetrovsk, Poltava and Kyiv oblasts lying in the Dnieper valley. The least developed, economically, parts of Ukraine are the Zakarpattia, Ternopil and Chernivtsi oblasts in western Ukraine, Zhytomyr in northern Ukraine, and Kherson in southern Ukraine. 
ix During the research period, the GDP per capita of the voivodeships of western Poland accounted for about $62-65 \%$ of the value of this variable in the Mazowieckie Voivodeship, central Poland $60-65 \%$ and eastern Poland only $45-50 \%$. What's more, because the GDP per capita in the most affluent voivodeship, that is, the Mazowieckie Voivodeship, in 2004-2016 increased by $64.0 \%$, in the provinces of western Poland by $57.6 \%$, central Poland by $50.4 \%$ and the poorest group of those voivodeships in eastern Poland by only $47.9 \%$, on the one hand, the development gap between the best-developed Mazowieckie Voivodeship and the rest of the country is growing and, on the other hand, the gap between the least-developed voivodeships of eastern Poland and other groups of voivodeships is also increasing.

x In Ukraine in 2004, the GDP per capita of the eastern Ukrainian oblasts constituted $72.6 \%$ of the value of this variable in northern Ukraine, and it was in central Ukraine $61.9 \%$, southern Ukraine $53.0 \%$, and western Ukraine only $42.0 \%$. In 2004-2017, the most prosperous regions of northern Ukraine were developing the fastest (total GDP per capita growth by $46.2 \%$ ), followed by central Ukraine (37.2\%), and then southern $(23.1 \%)$ and western Ukraine (16.0\%). In contrast, the GDP per capita of the eastern Ukrainian oblasts fell by as much as $29.0 \%$ during this timeframe. As a result, the development gap between the north of Ukraine and the rest of the country widened. In 2017, the GDP per capita of central Ukraine already accounted for only $61.9 \%$ of the value of this variable in northern Ukraine, while in southern Ukraine it was $45.6 \%$, eastern Ukraine $38.1 \%$ and in western Ukraine $34.2 \%$.

\section{Notes}

1 All charts given in this section regarding GDP or GDP per capita of the voivodeships are expressed in constant prices from 2015.

2 In 2016, Ukraine's nominal GDP amounted to 2,385.4 billion hryvnia, while Poland's was PLN 1,861.1 billion. The real GDP of Ukraine at PPP and fixed prices from 2010 was at that time USD 6,281.1 billion, and in Poland USD 917.8 billion (see https://w3.unece.org/). Therefore, the dollar was (according to PPP) was valued at 3.798 hryvnia or 2.010 PLN. From this comes the conclusion that 100 hryvnia from 2016, after including PPP, equaled PLN 52.9.

3 The fact that the capital of the state is also the most developed city (as is the case in both Poland and Ukraine) is by no means the rule. For example, the best developed cities of Germany are Hamburg and Munich, not the capital Berlin (Pastuszka 2016, 2017; Gomółka et al. 2017), while in Italy, the capital region of Lazio is much less developed than Lombardy or the province of Trentino-Alto Adige (Pastuszka, Tokarski 2017).

4 In 2004-2013, the average value of GDP generated in the Crimean Peninsula (i.e., in the Autonomous Republic of Crimea and Sevastopol) amounted to UAH 95.0 billion (3.6\% of the Ukrainian GDP).

5 In Kyiv, together with the Kyiv Oblast, the GDP per capita increased by $42.7 \%$, that is, $2.7 \%$ on average per annum. 